\title{
Universiteit
}

Leiden

The Netherlands

\section{Russia in the changing global order: multipolarity, multilateralism, and sovereignty}

Gerrits, A.W.M.; Hosli, M.O.; Selleslaghs, J.

\section{Citation}

Gerrits, A. W. M. (2020). Russia in the changing global order:

multipolarity, multilateralism, and sovereignty. In M. O. Hosli \& J.

Selleslaghs (Eds.), United Nations University Series on Regionalism (pp. 85-107). Cham: Springer. doi:10.1007/978-3-030-21603-0_5

Version: Publisher's Version

License:

Licensed under Article 25fa Copyright Act/Law (Amendment Taverne)

Downloaded from: $\quad$ https://hdl.handle.net/1887/3221100

Note: To cite this publication please use the final published version (if applicable). 
United Nations University Series on Regionalism 17

Madeleine 0. Hosli

Joren Selleslaghs Editors
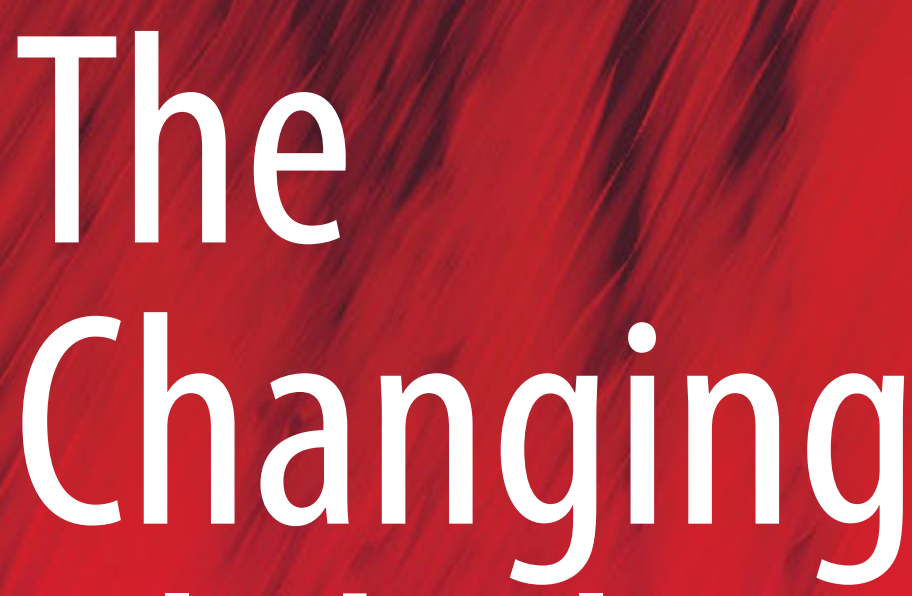

Global Order

Challenges and Prospects

Springer 


\section{United Nations University Series on Regionalism}

\section{Volume 17}

\section{Series Editors}

Philippe De Lombaerde, NEOMA Business School, Rouen (France) and UNU-CRIS, Brugge, Belgium

Luk Van Langenhove, Vrije Universiteit Brussel (VUB), Brussels, Belgium

UNU-CRIS, Bruges, Belgium

Glenn Rayp, Ghent University, Bruges, Belgium

Madeleine O. Hosli, Leiden University, The Hague, The Netherlands

\section{International Editorial Board members include}

Louise Fawcett, Oxford University, Oxford, UK

Sieglinde Gstöhl, College of Europe, Bruges, Belgium

Henryk Kierzkowski, Graduate Institute of International and Development Studies, Geneva, Switzerland

Fukunari Kimura, Keio University, Tokyo, Japan

Edward D. Mansfield, University of Pennsylvania, Philadelphia, PA, USA

T. Ademola Oyejide, University of Ibadan, Ibadan, Nigeria

Jacques Pelkmans, College of Europe, Bruges, Belgium

Joaquin Roy, University of Miami, Miami, FL, USA

Ramón Torrent, University of Barcelona, Barcelona, Spain 
The United Nations University Series on Regionalism, launched by UNU-CRIS and Springer, offers a platform for innovative work on (supra-national) regionalism from a global and inter-disciplinary perspective. It includes the World Reports on Regional Integration, published in collaboration with other UN agencies, but it is also open for theoretical, methodological and empirical contributions from academics and policy-makers worldwide.

Book proposals will be reviewed by an International Editorial Board.

The series editors are particularly interested in book proposals dealing with:

- comparative regionalism;

- comparative work on regional organizations;

- inter-regionalism;

- the role of regions in a multi-level governance context;

- the interactions between the UN and the regions;

- the regional dimensions of the reform processes of multilateral institutions;

- the dynamics of cross-border micro-regions and their interactions with supranational regions;

- methodological issues in regionalism studies.

Accepted book proposals can receive editorial support from UNU-CRIS for the preparation of manuscripts.

Please send book proposals to: pdelombaerde@cris.unu.edu and lvanlangenhove@ cris.unu.edu.

More information about this series at http://www.springer.com/series/7716 
Madeleine O. Hosli • Joren Selleslaghs

Editors

\section{The Changing Global Order}

Challenges and Prospects

望 Springer 


\author{
Editors \\ Madeleine O. Hosli \\ Institute of Security and Global Affairs \\ Leiden University \\ The Hague, The Netherlands
}

\author{
Joren Selleslaghs \\ Faculty of Governance and Global Affairs \\ Leiden University \\ The Hague, The Netherlands
}

ISSN 2214-9848

ISSN 2214-9856 (electronic)

United Nations University Series on Regionalism

ISBN 978-3-030-21602-3

ISBN 978-3-030-21603-0 (eBook)

https://doi.org/10.1007/978-3-030-21603-0

(C) Springer Nature Switzerland AG 2020

This work is subject to copyright. All rights are reserved by the Publisher, whether the whole or part of the material is concerned, specifically the rights of translation, reprinting, reuse of illustrations, recitation, broadcasting, reproduction on microfilms or in any other physical way, and transmission or information storage and retrieval, electronic adaptation, computer software, or by similar or dissimilar methodology now known or hereafter developed.

The use of general descriptive names, registered names, trademarks, service marks, etc. in this publication does not imply, even in the absence of a specific statement, that such names are exempt from the relevant protective laws and regulations and therefore free for general use.

The publisher, the authors, and the editors are safe to assume that the advice and information in this book are believed to be true and accurate at the date of publication. Neither the publisher nor the authors or the editors give a warranty, express or implied, with respect to the material contained herein or for any errors or omissions that may have been made. The publisher remains neutral with regard to jurisdictional claims in published maps and institutional affiliations.

This Springer imprint is published by the registered company Springer Nature Switzerland AG. The registered company address is: Gewerbestrasse 11, 6330 Cham, Switzerland 


\section{Contents}

Part I Theories of International Relations to Understand the Changing Global Order

1 Traditional Theories of International Relations.

Denise de Buck and Madeleine O. Hosli

2 Alternative Post-Positivist Theories of IR and the Quest for a Global IR Scholarship

Indraneel Baruah and Joren Selleslaghs

Part II The Changing World Order: The Rise of New Powers

3 Power Politics

Rob De Wijk

4 China's Ascent: A Strategic Perspective of Its Vision Jian Shi and Zeren Langjia

5 Russia in the Changing Global Order: Multipolarity, Multilateralism, and Sovereignty

André Gerrits

6 India as an Emerging Power: Understanding Its Meaning. Carina van de Wetering

7 Africa in the Changing Global Order: Does African Agency Matter in Global Politics? Fridon Lala

\section{Part III Regional Organisations in Global Affairs}

8 The Rise of Regions: Introduction to Regional Integration \& Organisations

Joren Selleslaghs and Luk Van Langenhove 
9 The European Union: Integration, Institutions and External

Relations in a Globalised and Regionalised World

Joren Selleslaghs, Mario Telò, and Madeleine O. Hosli

10 The Shanghai Cooperation Organisation

Giles Scott-Smith

11 ASEAN as a Conflict Manager: Lukewarm Mediation

Fathania Queen and Ying-Hsien Sheng

12 Regionalism in Latin America: Eclectic, Multi-faceted

and Multi-layered

Joren Selleslaghs, José Briceño Ruiz, and Philippe de Lombaerde

13 An Analysis of Regional Integration in South Asia

Indraneel Baruah

Part IV International Organisations and Global Governance 2.0

14 Global Governance 2.0

Amy E. P. Kasper

15 The United Nations Security Council: History, Current Composition, and Reform Proposals

Madeleine O. Hosli and Thomas Dörfler

16 NATO in a Changing World

Roger A. Tosbotn and Eugenio Cusumano

17 The Role and Effectiveness of the G20

Jaroslaw Kantorowicz

\section{Part V Conflict, Conflict Resolution and International Security}

18 The Enforcement of International Law 361

Elena Kantorowicz-Reznichenko

19 The International Norm Dynamics of Responsibility to Protect 385 Jérémie Speiser

20 Methods of Conflict Resolution: Negotiation 405 Paul Meerts

21 Debunking the Myths of International Mediation:

Conceptualizing Bias, Power and Success

Siniša Vuković

Closing Remarks 


\section{Editors and Contributors}

\section{About the Editors}

Madeleine O. Hosli is full Professor of International Relations and a Jean Monnet Chair ad personam at Leiden University. She is also the Director of the two-year advanced MSc in International Relations and Diplomacy. She is Author of The Euro: A Concise Introduction to European Monetary Integration (2005) and a Coeditor of Decision-Making in the European Union Before and After the Lisbon Treaty (2015). Her work has appeared in journals such as International Organization, International Studies Quarterly, Journal of European Public Policy, European Journal of Political Research, Journal of Common Market Studies, Review of International Organizations, Governance, Political Studies and Journal of International Relations and Development.

Joren Selleslaghs is the Belgian Consul for Peru, Bolivia, and Ecuador since October 2018. He entered the Belgian Ministry of Foreign Affairs as a Diplomat in October 2017 and has worked at the Brussels headquarters (Brexit, Benelux, Consular Affairs) and the Belgian Embassy in Luxemburg as diplomatic Counselor.

He graduated cum laude from the College of Europe (MA EU International Relations and Diplomacy Studies) and magna cum laude at the Institute for European Studies of the Université Libre de Bruxelles (MSc European Studies). He previously worked as a Lecturer and Researcher on the EU and International Relations at Leiden University, and as an Associate Research Fellow at the United Nations University Institute of Comparative Regional Integration Studies, UNU-CRIS (Belgium). He also worked as an EU Innovation Consultant at PNO Consultants (the Netherlands), at The Hague Centre for Strategic Studies, the cabinet of a Belgian Member of the European Parliament, and the External Relations department of the Belgian Permanent Representation to the European Union. Until October 2017, Joren Selleslaghs was also an external evaluator/expert for the European Commission and member of the Board of Directors of the Europe-Central America Chamber of Commerce. He was the Belgian Youth Ambassador toward the 
UN in 2011-2012 and also active as a development worker for UNICEF in Tanzania and Central America (2007-2008 and 2012).

\section{About the Contributors}

Indraneel Baruah is a recent graduate from Leiden University, where he attained his MSc in International Relations and Diplomacy. He wrote a master's thesis (cum laude) on Regional Integration in South Asia: An investigation of the Kashmir conflict and prospects for international mediation. Prior to this, he received his Bachelor of Arts (BA) degree in Political Science (Honours) from Hindu College, University of Delhi. He is currently an EU Research and Innovation Consultant at PNO Consultants. He has consulted a range of organisations including Shell, BNP Paribas, DISA, Scania, CNH Industrial Europe and various institutions of higher education within Europe. He has also been a Research Assistant at the Faculty of Governance and Global Affairs, Leiden University. Currently, he is on a 1-year sabbatical from PNO, conducting research in his home state of Assam, India. The research is focused on the migration crisis between India and Bangladesh, which is centred in India's North-Eastern Province of Assam. In addition, he works part-time as a Research Consultant at ActionAid.

Denise de Buck currently works as Head of the Donor Management Department for the International Humanitarian Mine Clearance Organization the HALO Trust in Afghanistan. Previously, she completed a traineeship at the European External Action Service (EEAS) in Brussels, dealing with conflict prevention, security sector reform and post-conflict peacebuilding and stabilisation. She holds an MSc (cum laude) in International Relations and Diplomacy from Leiden University.

Eugenio Cusumano is an Assistant Professor in International Relations at Leiden University. His research concentrates on the role of non-state actors in military operations and humanitarian crises both on land and at sea. He has published for leading academic outlets like Stanford University Press, Journal of Strategic Studies, Cooperation and Conflict and Armed Forces \& Society.

Philippe de Lombaerde is currently Associate Professor of International Economics at NEOMA Business School (Reims, Rouen, Paris). Previously, he was Associate Director at the United Nations University Institute on Comparative Regional Integration Studies (UNU-CRIS) in Bruges and Associate Professor of International Economics at the National University of Colombia.

Rob De Wijk is the Founder of The Hague Centre for Strategic Studies (HCSS) and Professor of International Relations and Security at the Institute of Security and Global Affairs, Leiden University. He studied Contemporary History and International Relations at Groningen University and wrote his $\mathrm{PhD}$ dissertation on 
NATO's 'Flexibility in Response' strategy at the Political Science Department of Leiden University. He started his career in 1977 as a Freelance Journalist and later became Head of the Defence Concepts Department of the Dutch Ministry of Defence, Head of the Security Studies unit at the Clingendael Institute and Professor of International Relations at the Royal Netherlands Military Academy.

Thomas Dörfler holds a PhD in Political Science from the University of Bamberg, Germany, and a master's degree from Leiden University, the Netherlands. He has been a Japan Society for the Promotion of Science (JSPS)-UNU Postdoctoral Research Fellow with the UNU Centre for Policy Research, a Visiting Scholar at John Jay College of Criminal Justice (City University of New York) and a Consultant for the Security Council Affairs Division of the UN Secretariat. Most recently, he held a postdoctoral position at the Technical University Munich (Germany) (TUM) School of Governance and currently holds a research fellow position at the University of Potsdam (Germany). He has published in academic journals including Regulation \& Governance; Global Governance: A Review of Multilateralism and International Organizations; Journal of International Relations and Development; Terrorism and Political Violence; and Journal of Economic Policy Reform, as well as several chapters in edited volumes and policy-relevant articles. For his work on UN sanctions, he has received the 2018 Hans-Löwel Prize and the 2017 Award of the UN Association of Germany.

André Gerrits is Professor of International Studies and Global Politics and Chair of the MA International Relations (European Union Studies/International Studies) and the BA International Studies, based in The Hague. Previously, he held the Chair in Russian History and Politics at Leiden University and the Jean Monnet Chair in European Studies at the University of Amsterdam. He was also a Senior Research Fellow at the Netherlands Institute of International Studies Clingendael.

Rory Johnson currently works within the Office of the Director at the United Nations Institute on Comparative Regional Integration Studies (UNU-CRIS) in Brugge, Belgium. He is a graduate of Leiden University, where he attained an MA in International Studies (cum laude). He is also pursuing an MSc in Environmental Studies at Bangor University in the UK. His specific interests are in environmental governance and security and development issues in Africa.

Jaroslaw Kantorowicz is an Assistant Professor at the Institute of Security and Global Affairs, Faculty of Governance and Global Affairs, Leiden University. He graduated (summa cum laude) from the European Doctorate in Law and Economics (Hamburg University). His research interests are focused on global economic governance, political economy, intergovernmental fiscal relations and empirical legal studies. In the past few years, he has been collaborating on various projects with the European Commission, the European Parliament and the Organisation for Economic Cooperation and Development. 
Elena Kantorowicz-Reznichenko is a Researcher and a Lecturer at Rotterdam Institute of Law and Economics, Erasmus School of Law, Erasmus University Rotterdam. Her main areas of expertise are public law and economics, international criminal law and behavioural and experimental law and economics. In addition, she is the Academic Coordinator of the European Doctorate in Law and Economics (EDLE). She holds multiple academic degrees from different internationally recognised universities in the fields of law, psychology and law and economics. Prior to her academic career, she worked as a Criminal Prosecutor in the District Attorney's Office in Israel. She published in a variety of prestigious international journals, such as Journal of International Criminal Justice (forthcoming 2017), Washington University Law Review (forthcoming 2018), International Review of Law and Economics.

Amy E. P. Kasper is a PhD student at the University of St. Gallen in Switzerland. She has earlier been a Researcher at the Institute of Security and Global Affairs at Leiden University. She is a recent graduate (cum laude) of Leiden University's MSc in International Relations and Diplomacy. She wrote her MSc thesis on patterns of compliance within international human rights law, tying these patterns to the presence/absence of domestic acceptance of international norms. Her background has been shaped by her time working on the terrorism and counterterrorism team at Leiden's Institute of Security and Global Affairs, as a Programme Officer at the World Affairs Council in Seattle, managing professional exchange programmes for the US Department of State, and as a Teacher of English as a second language in multiple countries.Recently, she worked as a Tutor/Lecturer for Leiden University's minor in Global Affairs.

Fridon Lala is a Graduate Student in Public Administration at the School of Public Policy, Central European University, in Budapest. He is specialising in governance, focusing on governance beyond the nation-state, and related changes to the structure of the global political economy. He has conducted an internship at the United Nations University Institute on Comparative Regional Integration Studies (UNUCRIS) in Bruges, Belgium.

Zeren Langjia is a Doctoral Researcher of the Centre for European Studies of Sichuan University, China, and Department of Political Science of Ghent University, Belgium. His research focuses on the Normative Power Europe and the EU's external policy.

Paul Meerts is Senior Associate with the Netherlands Institute of International Relations 'Clingendael' at The Hague, Netherlands, and an International/Diplomatic Negotiation Analyst. He holds a PhD in International Public Law from Leiden University (2014). He is a Member of the Steering Committees of the network Processes of International Negotiation (PIN) and Founder of the Program on International Negotiation Training (POINT), as well as Advisor to the journal International Negotiation. 
Fathania Queen Genisa is currently working in the Governor's Delivery Unit of Special Capital Region of Jakarta as a Member of the staff. She studied at Leiden University, where she obtained her MSc degree in International Relations and Diplomacy degree and took her Bachelor's degree at the Universiti Utara Malaysia. She had working experience at the Grotius Centre for International Legal Studies in which she worked on issues related to non-state actors in global governance. Before that, she worked at the Indonesian Teaching Movement (Jakarta, Indonesia) and the Institute of Diplomacy and Foreign Relations (IDFR) in Malaysia.

Ewout Ramon was formerly a Research Assistant to the Director at the UNUCRIS. He acted as UNU-CRIS' focal point in the UNU network for communications, ICT and project management and coordinated the UNU-CRIS internship programme. Prior to joining UNU-CRIS, he obtained a bachelor's degree in International Politics from the University of Ghent and a master's degree in European Studies: Transnational and Global Perspectives from the University of Leuven before starting at UNU-CRIS as a Communication Intern in April 2013. As an Exchange Student, he also spent one year studying international relations at Istanbul Bilgi University in Turkey. He currently works as a Project Coordinator in the International Affairs Department at Voka, the Flanders' Chamber of Commerce and Industry, West Flanders.

José Briceño Ruiz holds a PhD in Political Science from the Institut d'Études Politiques d'Aix-en-Provence, France. He is Professor and Researcher at the Faculty of Economics and Administration and the Centro de Pensamiento Global (CEPEG) at the Universidad Cooperativa de Colombia. He was Professor at the Faculty of Social and Economic Sciences of the University of the Andes, Venezuela, between 2003 and 2017. He is a Specialist on Regional Integration and International Political Economy. He has written and edited books on regional integration, the most recent of them being Brazil and Latin America: Between the Separation and Integration Paths (Lanham, Maryland: Lexington Books, 2017) in collaboration with Andrés Rivarola Puntigliano and Post-Hegemonic Regionalism in the Americas: Toward a Pacific-Atlantic Divide? (London: Routledge, 2017) in collaboration with Isidro Morales (Tec de Monterrey).

Giles Scott-Smith holds the Roosevelt Chair in New Diplomatic History at Leiden University and is the Academic Director of the Roosevelt Institute for American Studies in Middelburg, the Netherlands. From 2013 to 2016, he was Chair of the Transatlantic Studies Association. In 2017, as one of the Organisers of the New Diplomatic History Network (http://www.newdiplomatichistory.com), he was one of the Founding Editors of Diplomatica: A Journal of Diplomacy and Society published with Brill.

Ying-Hsien Sheng was born in Taiwan in 1982. She studied political science at Tunghai University, where she received her doctor's degree in 2012. She proceeded to serve in some local universities, such as the National Chung Hsing University, 
Central Taiwan University of Science and Technology, Providence University and Tunghai University, as Adjunct Assistant Professor for years. Her articles have been included in the Journal of National Development Studies, International and Public Affairs, Journal of Law and Public Governance, Review of Global Politics, Tamkang International and Area Studies Semiannual, Chang Gung Journal of Humanities and Social Sciences, among others. She has passed the Level One Civil Service Senior Exam and worked for the government since February 2018.

Jian Shi is Jean Monnet Professor in European Society and Director of the Jean Monnet Centre of Excellence at the School of International Studies, Sichuan University, Chengdu, China, where he lectures in European Studies. He has a PhD from Lehigh University, PA, USA. His research focuses on European civilisation and EU-China relations, particularly on the bilateral cooperation in higher education.

Jérémie Speiser is an Assistant Administrator at the Council of Europe in Strasbourg and follows up on the work of the Steering Committee for Human Rights (CDDH) regarding the system of the European Convention on Human Rights. His academic interests focus on international mechanisms for the protection of civilians in situations of conflict and/or humanitarian distress. Prior to that, he was an Intern at the Organisation for the Prohibition of Chemical Weapons (OPCW) and the International Criminal Court (ICC). He holds a Master of Science degree in International Relations and Diplomacy from Leiden University and a Bachelor of Arts in War Studies from King's College London.

Mario Telò is an Italian Political Scientist and Researcher who focuses on European studies, political theory and international relations. He has been a Researcher and Professor in many European, Asian and American universities. Since 1995, he has been a 'Jean Monnet Chair' and, since 2006, a Member of the Royal Academies for Science and the Arts of Belgium.

Roger A. Tosbotn is a Temporary Project Officer at the Financial Mechanism Office of the EEA and Norway Grants in Brussels, having completed a 12-month traineeship in the same organisation. He obtained his master's degree diploma from Leiden University in 2016, specialising in international security, international organisations and global politics. His master's thesis, NATO and Cyber Security: Critical Junctures as Catalysts for Change, was an in-depth quantitative and qualitative content analysis of the prominence and conceptualisation of the 'cyber' concept over time. He has also worked on the 510.global Red Cross Netherlands initiative where he, among other things, helped develop a Data Responsibility Policy. Additionally, he has assisted Dr. Eugenio Cusumano in a research project on hybrid threats commissioned by the NATO CIMIC Centre of Excellence. This project was published by Palgrave Macmillan.

Carina van de Wetering is a Lecturer at the Leiden University Department of Political Science, the Netherlands. She received her PhD in Politics at the University 


\title{
Chapter 5 \\ Russia in the Changing Global Order: \\ Multipolarity, Multilateralism, and Sovereignty
}

\author{
André Gerrits
}

\subsection{Introduction}

The foreign policy of any country, including major powers like Russia, is determined by multiple variables, some of which it can influence, but others it cannot. Some factors are of a domestic nature, while others relate to the international environment. None of these variables are fixed. They are dynamic and change over time. Domestic conditions not only relate to the political nature of the regime (authoritarian, democratic) and to the state of the economy, but also to deeper structural conditions like geography, culture and history. Material and immaterial power resources can also be relevant, from energy reserves and other material assets as deployable military forces, to less tangible, political assets as the willpower, the effectiveness and the legitimacy of political leadership.

The weight of international factors is more difficult to assess. The most important variable is of course the same combination of material and immaterial power of other states, including their economic, military and other resources. Power is relative and relational. It is not only about measurable assets but also about the extent to which states are able to generate desired outcomes. A country can enhance its regional or global influence through membership of international organizations and alliances. If we consider these domestic and international variables, we recognize why and how Russia's foreign policies have fluctuated so dramatically since the early 1990s. We understand why the foreign policy of president Boris Yeltsin (1991-2000) differed strongly from that of his successor, Vladimir Putin. And its also explains why Putin's first two terms as president (2000-2004, 2004-2008), contrasted with his third (2012-2018) and fourth (from 2012) ones.

\footnotetext{
A. Gerrits $(\bowtie)$

Institute for History, Leiden University, Leiden, The Netherlands

e-mail: a.w.m.gerrits@hum.leidenuniv.nl
} 
Yeltsin's domestic power resources were extremely limited. During the early 1990s Russia was in a deep crisis. The political leadership was extremely divided. The popularity of the president was low, and the power of the government was weak. For his re-election in 1996 president Yeltsin had to turn for support to Russia's powerful oligarchs. During the first decade after the Cold War Yeltsin's realistic foreign policy options were few. The United States was exceptionally powerful, a hyper-power in an essentially unipolar world. The Zeitgeist was uniquely universalist. The world seemed one, dominated by a superior, self-confident 'West' (the United States and the countries of the European Union). One could argue that the leaders of Russia did not carry many more options than a pro-Western foreign policy - and that was precisely what Yeltsin did during the first years of his presidency, in the interest also of his domestic reform agenda.

A decade later, the situation had changed profoundly. In the spring of 2000, after a brief but powerfully orchestrated media campaign, Putin was elected president of Russia. Within a remarkably short period of time, he managed to consolidate his personal power and strengthen Moscow's control over the country, including the unruly North Caucasus. Putin subdued, exiled and in the case of Yukos CEO Mikhail Khodorkovsky imprisoned the same oligarchs that had saved Yeltsin's re-election a few years earlier. In comparison with Yeltsin's, Putin's leadership was practically undisputed, legitimate, and effective. Putin's rule also benefited from changes beyond its control. Global economic growth drove the price of energy up. Russia was able to pay off its international debt and to build a substantial financial reserve. The political confidence of Russia's elite increased proportionally with the price of a barrel of Ural crude oil. Meanwhile in the United States, the sense of triumphalism that had followed the Cold War, had suffered from the terrorist attacks on 9/11 and the two wars the United States chose to start but could not decisively win, in Afghanistan and Iraq. The deepest financial crisis since the Great Depression (from 2008) added to the problems of the West. It undermined the image and prestige of Western powers and accelerated their further relative decline. In Europe the global financial crisis hit not only individual countries, but also dangerously undermined the process, if not the very idea of European integration. Europe turned inward, struggling with a persistent economic malaise, rising Euro scepticism, and a deepening crisis of confidence.

Russia was not immune to adverse global economic developments. The world financial crisis plunged the country into a depression, from which it recovered quickly though. The volatility of energy prices impacted the state budget positively for most of the 2000s, but negatively from 2013/2014. Consecutive presidential terms by Putin and Dmitri Medvedev (2008-2012) achieved little to improve the structural weakness and vulnerability of Russia's economy. Politics is short-term business though, and the combination of favourable domestic and international conditions boosted Russia's self-confidence and positively impacted on the country's foreign policy and international prestige. Russia acquired a more prominent and politically autonomous position within a global order that became gradually less liberal and less dominated by the West. 
This contribution will zoom in on two related aspects of Russia's foreign policies within a changing global context: ideas about multipolarity and multilateralism. It begins by analysing the particular worldview of Russia's leaders, and key aspects of Russian foreign policy, revisionism, pragmatism and sovereignty. Subsequently it discusses how Russia's specific idea of multipolarity and its strategy of multilateralism relate to the country's core foreign policy ambition, that is to revise the global order by strengthening its own power and sovereignty?

A few words about foreign policy decision-making in Russia seem in order. Although we do not necessarily know more about the inner workings of the Kremlin today, than we did in communist times, it may be safely assumed that among the multiple institutions involved in the decision-making process, the office of the president is key. The Constitution gives the president 'leadership of the foreign policy of the Russian Federation'. The president defines the basic direction of foreign and security policies, approves the foreign policy and security doctrines, serves as commander-in-chief, and so forth. As important as the institutions of the state in Russia are, they are trumped by individuals and informal networks. During the Medvedev presidency, foreign policy decision-making prerogatives partially shifted with Putin to the prime minister's office. From Putin's return to the presidency, formal and informal politics converged again. Bobo Lo $(2015,13)$ probably rightly asserts that in Russian foreign policy 'all big decisions go through Putin in some form or other'.

\subsection{How Russia Sees the World}

The core of the foreign policy perspective by the Russian political elite is the integral link between the country's domestic order (including the interests of its supreme elite), its foreign policies and its global status. The overall foreign policy ambition, as James Sherr $(2013,96)$ defines it, is 'the creation of an international environment conducive to the maintenance of its system of governance at home' (italics in original). And national interest means regime interest. 'Only when Russia is strong and stands firmly on its own feet, will it be treated with respect', Putin emphasized in a campaign article before the presidential elections of 2012 (Putin, February 2012). Russia projects adequate sovereign power, i.e. hard power, or she will be at the mercy of other powers, thereby putting the sheer survival of the Russian state at risk. In other words, Russia is a great power or Russia is not! It is this simple but urgent lesson that Russia's leadership and foreign policy elite learned from the collapse of the Soviet Union and the deep crisis of most of the 1990s. Derzhavnost is the crucial notion. Derzhavnost has no equivalent in either the English language or in the Western tradition. The French étatisme comes closest, but even étatisme does not have the deep cultural connotation and the unique flavour that derzhavnost has in the Russian language: the crucially important combination of a strong state and a great power. 
Global politics is nasty, brutish, and anarchic. This typical Hobbesian or realist view of world politics is broadly shared among politicians and scholars in Russia (Sergunin 2004; Tsygankov and Tsygankov 2003). Russian scholarship copies the theoretical divides of Western, especially American international relations research: realism, liberalism, and constructivism. Typically Russian features mostly concern the direction of foreign policy, rather than the analysis of global politics. In the early years of international relations discourse in Russia after 1991, the distinction between 'Atlanticism' and 'Eurasianism' was especially influential. The former orientation favoured the pro-Western policies of president Yeltsin and his minister of Foreign Affairs Andrei Kozyrev; the latter, shared by a larger and more heterogeneous but initially less influential group of scholars, emphasized the distinctiveness of Russian civilization and the need to balance between East and West. These scholars prioritized relations with the countries of the former Soviet Union over partnership with the West. Two decades later, Atlanticism has almost disappeared from foreign policy discourse in Russia; whilst Eurasianism in all its diversity blossoms. Eurasianism has deeply penetrated official discourse. It serves as an ideological driver for strengthening Russian influence in the Eurasian region (the former Soviet space) and for supporting policy initiatives as the Eurasian Union-a fundamental component of Putin's foreign policy strategy of multipolarity and great power balancing.

In the Russian realist interpretation domestic and international security are firmly linked. The narrative remained over the years, but the analysis partially changed. Russian realists agreed that the gravest threat to Russia's security initially came from within, from the country's deep internal crisis (Sergunin 2004; Tsygankov and Tsygankov 2003). That danger has now been averted, and the focus has shifted to old/new threats from without: instability along Russia's borders, cross-bordering crime and terrorism and, conspicuously present during Putin's presidency, the dangers that emanate from US or Western unilateralism and interventionism.

If the predominance of the realist interpretation of global politics is not particularly controversial among Russia scholars, more contentious are the normative drivers of Russian foreign policy. Honour is often mentioned. Andrei Tsygankov (2012) combines realist and constructivist perspectives, and explains Russia's varying approaches towards the West - cooperation, defensive reaction, and assertivenessby its profound sense of honour. Russia is deeply concerned about its position among the world's great powers. Apart from honour, related concepts as status (Larson and Shevchenko 2014) and prestige (Donaldson et al. 2014, 383) are also considered as powerful logics of Russian foreign policy. It is imperative to add, though, that immaterial factors have driven Russian foreign policy in different directions. Yeltsin's cooperative strategy and Putin's confrontational policies can both be explained by these leaders' desire to seek global political status and to be accepted as an equal partner. (Larson and Shevchenko 2010, 63). 


\subsection{Revisionism}

A foreign policy that intends to reach global pluralism or multipolarity aims to change international power relations. Is Russia a revisionist power? And if so, what does Russia aim to revise, and what does it want to remain?

Russian foreign policy undeniably has a revisionist aspect. It comes from the combination of its former great power status (a feature, with interruptions, of Russia's international position and self-perception from the early nineteenth century), its collapse and retrenchment during the 1990s, and its economic growth, political revival and growing presence in the international system from the early 2000s. Russia has a complex relationship with the global liberal order that reigned supreme after the Cold War. The Soviet Union was the ultimate outsider, a challenger of the liberal order per se. Post-communist Russia was in a more ambiguous position. Its trajectory went from initial adjustment to the socioeconomic and international-political features of the liberal international order, to the increasing emphasis on the special and unique nature of Russia and its interests, a separate pole in a pluralistic world order.

Yeltsin's early attempts to integrate more closely with the West and to adapt to the dominant liberal order are now generally considered in Russia as naive and harmful. It was a brief, contested but still a defining moment in Russia's recent history. In the early 1990s Russia adopted the institutions of liberal democracy, but not its rules, its standards. Russia became the archetypical example of a democracy with adjectives, like illiberal, managed or authoritarian democracy, while turning increasingly authoritarian. (Levitsky and Way 2010) Yeltsin's predominantly pro-Western strategy did not survive his first presidential term. From the mid-1990s Russia's foreign policy approach moved into a different direction, less reactive and submissive, and more firmly geared towards Russia's apparently unique global position and corresponding interests and ambitions. This foreign policy change is generally associated with Yeltsin's minister of Foreign Affairs from 1996-1998, Yevgeny Primakov and his emphasis on multipolarity. Multipolarity remained a cornerstone of Russia's foreign strategy ever since. It coexisted with different policies, from moments of rapprochement and cooperation with the West, especially during Putin's first (2000-2004) and Medvedev's only presidential term (2008-2012), to periods of antagonism and conflict, especially after the Crimea crisis (2014). The persistence of multipolarity reflects how Russia continues to see itself as a relative outsider from the West. The civilizational distinction between Russia and the West is routinely used in Russian discourse today. There are few other countries where Huntington's idea of a 'clash of civilizations' (Huntington 1996) is as popular and as frequently referred to by policy-thinkers and policy-makers, as Russia.

Russia's perceived revisionism is often discussed in the context of another, related feature of the post-Cold War global order, that of emerging powers-a 
notion that is often associated with the BRICS countries. ${ }^{1}$ Russia has never been 'just' an emerging power though, neither economically nor politically. In relative economic terms Russia is a declining rather than an emerging power. Its economy has grown considerably over the last two decades, though not as impressive as most other emerging economies, and with serious lapses. With a Gross Domestic Product of slightly over 1.331 billion US dollars, Russia reached thirteenth in 2015 in the World Bank global ranking, the smallest of the original BRIC countries and far behind the United States (18.036 billion USD) and China (11.007 billion USD) (World Bank 2015).

Russia's longer-term economic prospects are mixed, but they do not seem to justify its ranking among the emerging markets of today. If Russia can be considered as an emerging power at all, it is not for its economic but for its political potential. And it is also for political reasons that the Russian leadership values its affiliation with the BRICS community. The BRICS are not an organization, not an alliance, but essentially a series of agreements among sovereign states. Partnership with the other BRICS countries does not in any way limit Russia's independence, but it adds to its international reputation. BRICS provides Russia with an important platform to present its ideas and ambitions about global reform.

Public relations is an important aspect of Russia's BRICS strategy. Putin as a leader may appeal to people around the globe, but Russia as a country has a weak international reputation. The BRICS story is one of the instruments used by the Russian leadership to strengthen its brand name. Around the time of the formalization of political cooperation by the BRICS countries, the Foreign Policy Concept of the Russian Federation promised that Russia would commit 'even more explicitly' to formats such as the G8 and BRIC, and to actively use 'these and other informal ways and structures for dialogue'. (Foreign Policy Concept of the Russian Federation 2008) In Russia's latest Foreign Policy Concept (December 2016), BRICS is ranked among the partners with which Russia intends to further expand its ties, together with the United Nations, the Group of 20, the Shanghai Cooperation Organization and the Cooperation between Russia, India and China (RIC). In this edition the G8, from which Russia was removed after the Crimea crisis, was understandably absent.

The future political relevance of BRICS depends on a series of factors on which Russia has only limited leverage. It is China and not Russia who defines the geostrategic and financial weight of BRICS. Generally, the strategic interests of the BRICS diverge considerably. South Africa and Brazil are regional powers. They cherish modest global ambitions. India, the soon-to-be most populous country in the world, has wider ambitions, but its security agenda is still mostly filled with regional issues, especially its relations with Pakistan and China. Russia is as much a re-emerging or 'recovering' power (MacFarlane 2006), as it is an emerging one. She is a great power not only by virtue of her size, nuclear arsenal, and energy resources, but also

\footnotetext{
${ }^{1}$ The BRICs notion was coined by Jim O'Neill (2001), Goldman Sachs. It refered to what he saw as the four major emerging market economies: Brazil, Russia, India, and China. The idea of BRICs became increasingly politicized, which was also the major reason why in 2010 the Republic of South Africa 'joined' this loose association of states, which from then on was known as BRICS.
} 
because she is the successor state to the super power Soviet Union. Russia inherited its most prestigious symbol of great power status, its permanent seat in the UN Security Council, from its predecessor. Russia is deeply involved in the political and economic architecture of the post-Cold War world. Russia, and the same goes for China, have benefited greatly from the wave of globalization from the early 1990s. In short, Russia's relationship with the West and with the liberal order that the United States built is too deep and too multifaceted to simply define Russia as a fully revisionist power. Russian foreign policy has evident conservative traits. Russia is a revisionist and a status-quo power. Russia has much to defend in the current global order. As Richard Sakwa $(2016,6)$ puts it, Russia is a neo-revisionist power, 'challenging the practices but not the principles of international order'. Russia's strategy is not so much about changing the international order, as it is about strengthening its role within this order.

\subsection{Pragmatism}

The Putin leadership consistently labels Russia's foreign policy as pragmatic, and many scholars tend to agree (Donaldson et al. 2014, 363; Kuchins and Zevelev 2012; Rowe and Torjesen 2009). In its dealings with other powers Russia makes little distinction on domestic order, political ideology or international orientation. For most of its post-communist history, Russia maintained good relations with Western democracies, non-Western countries, including most emerging powers, and outliers, like Syria and Iran. Did the annexation of the Crimea and the intervention in the Syrian war represent a break with Russia's relatively pragmatic and partial revisionist foreign policies?

Russia's decision to militarily intervene in the Crimea and to go to war in Syria came unexpectedly and they were crucial moments in Russia's recent foreign policy trajectory. Post-Communist Russia has not been a particularly war-prone country. Over the past two decades Russia has been much less involved in large-scale military conflict than the US and some of its allies, and never beyond the borders of the former Soviet Union. The intervention in Syria was a novelty, risky, and with unforeseen military and diplomatic consequences, but the political rationale of it matched with the longer-term ambitions of the Putin leadership (Allison 2013). The intervention reflected various key ambitions of Russian foreign policy. It qualified Russia to play a crucial role in the future of Syria, if not of the Middle East as a whole. It confirmed Russia's international presence, and as such it was another step towards the global multipolar order that Russia's aspires. And paradoxically it strongly supported the claim by the Russian leadership that external intervention and regime change (examples: Iraq 2003 and Libya 2011) were largely responsible for the violent chaos and conflict in the Middle East. Russia's intervention in the Syrian civil war was therefore aimed at the exact opposite: to save the Assad regime and to prevent the imminent collapse of the Syrian state. And it speaks to the sophistication of Russia's diplomacy that the negative consequences of Russia's 
intervention remained limited. Russia remains on relatively good terms with most countries in the region, including traditional adversaries as Israel and Iran, the Gulf States, and organizations as Hezbollah (Phillips 2016). Only relations with the United States and its European allies, whose relative passivity had encouraged Russia's to intervene, further soured. They reached a new low, a year after Russia's annexation of the Crimea.

The Crimea in the spring of 2014 was not the first instance of Russian uninvited military intervention in a neighbouring country, a former Soviet republic. In 1992 Russian troops had interfered in the armed conflict between Moldova and the breakaway Transnistrian territory. As yet, they haven't left. In August 2008, Moscow sent troops into Georgia, after hostilities between Georgian government forces and Russia-backed local militias had broken out in the separatist region of SouthOssetia. Russia supported the quasi-independence of South-Ossetia and Abkhazia and its subsequent policies towards the Georgian regions came close to actual annexation (Gerrits and Bader 2015). But the military intervention in the Crimea, the referendum on its future status, and the formal incorporation of the peninsula into Russia was an even more blatant violation of international law. Never before had Russia formally annexed part of the territory of one of its neighbours. But was it an irrational move, a deviation from Russia's relatively pragmatic foreign policy tradition?

First, the annexation of the Crimea cannot be measured by foreign policy criteria only. There have been few foreign policy issues that were so much driven by domestic sentiments and concerns as the relationship with Ukraine and the future of the Crimea. And a from a domestic policy perspective, the occupation and annexation of the Crimea yielded significant profits. It further boosted the popularity of the Putin presidency.

Secondly, the diplomatic fall-out of the annexation of the Crimea was serious, but it remained mostly limited to Russia's relations with the West. Beyond the United States, Europe and its allies, the annexation of the Crimea had little diplomatic repercussions. It may have longer-term consequences though in Russia's relations with some of the countries in the former Soviet space. Russia's friends in the region showed only lukewarm support for the annexation of the Crimea (Dragneva 2016; Kropatcheva 2016). The reaction by Belarus, Armenia and Kazakhstan was not very different from their earlier refusal to recognize the independence of Abkhazia and South-Ossetia. Russian belligerence in its geopolitical environment unnerves the other former Soviet republics, especially those with substantial Russian minorities, like Kazakhstan.

Finally, returning to domestic issues again, the annexation of the Crimea occurred within a context of rising nationalism in Russia. The conservative and nationalist turn which Russian politics took after Putin's return to the presidency in 2012 is generally explained as the response by a cornered regime. Putin apparently felt threatened by mass protests against the outcome of the parliamentary and presidential elections in 2011-2012, and turned to nationalist rhetoric to boost his popular support. Nationalism played a classical role. It was supposed to provide the ruling elite with an instrument to raise its legitimacy, without addressing the protestors' 
real political grievances. Given also the rising tide of nationalism in Russia, the annexation of the Crimea was expected to receive strong support in Russian society, and it apparently did.

However, the new nationalism in Russia can also be explained differently, without questioning its strongly functionalist nature. It was the absence, rather than the presence of radical, state-sponsored nationalism which had distinguished political developments in Russia since the early 1990s. The political relevance of nationalism in post-communist Russia had remained remarkably low, given the deep economic crisis during most of the decade, the country's weakly developed political and social institutions, in combination with the unpopularity of the Yeltsin leadership and the relative openness of its political arena (Lieven 1999). Theoretically, post-communist Russia was an ideal candidate for Jack Snyder's thesis that early and partial democratization easily leads to nationalist conflict (Snyder 2000).

In this context, the rise of nationalism in Russian politics could also be interpreted not as a move into a radical or extremist direction, but as a 'catching-up' development, or perhaps as a 'return to normalcy' (Laruelle 2010). The Putin leadership allegedly perceives the relatively weak sense of national identity (Riasanovsky 2005 , 231) among the Russian population as a political liability. As Putin put it in September 2013 before an international meeting of Russia specialists: '(Russia needs) to preserve (its) identity in a rapidly changing world (...) It is impossible to move forward without spiritual, cultural and national self-determination (...)' Putin stressed the civic, as against the ethnic nature of state sponsored nationalism. 'Nationalists must remember that by calling into question our multi-ethnic character (...), means that we are starting to destroy our genetic code. In effect, we will begin to destroy ourselves.' (Putin, September 19, 2013).

\subsection{Multipolarity}

Independence and self-determination are the most frequently professed norms of foreign policy by the Russian leadership. A 'highly restrictive interpretation of domestic jurisdiction and sovereign rights', as MacFarlane $(2006,49)$ puts it, determines Russia's interpretation of global politics and international relations. Sovereignty and non-intervention, or 'the primacy of international law' as the Russian leaders prefer to phrase it, is the crucial link between their domestic and foreign policies. It is the major logic of Russia's ambition to create a multipolar, a pluralist global order.

The Russian leadership claims to unequivocally support the principle of sovereignty, territoriality and non-intervention, but it does not always act accordingly. Russia rejects any interference into its own internal affairs and neither is it very demanding about the domestic political order, ideological viewpoints or even foreign policy orientations of its international partners. Different from the United States and some West European countries, and from the Soviet Union of course, Russia has never been seriously engaged in the promotion abroad of its political 
values or domestic system. But there is one important exception, the countries of the Former Soviet Union. Russia is strongly focused on the internal and international developments of its neighbouring countries. Only in its 'Near Abroad' has Russia intervened militarily in the internal affairs of other countries, also for reasons of regime-change or to defend an authoritarian political order. ${ }^{2}$

Sovereignty and self-determination are also the cornerstones of what can be considered as Russia's main foreign policy ambition: a pluralistic or multipolar global order. In Russia's view multipolarity represents a global system, which consists of different geopolitical poles, each dominated by one or more leading powers. These powers are sovereign and equal, and they share a common responsibility for global peace and stability. Russia is meant to be one of these poles. Multipolarity appears in every major foreign policy document since the Cold War. It is Russia's answer to the post-Cold War global dominance of the United States and its tendency towards unilateralism, which Russia considers as a danger to global peace and as a threat to its own security.

Scholarship differs on the relationship between global multipolarity and stability. Some consider multipolarity as a relatively benign system, wherein states compete and cooperate with each other (Donaldson et al. 2014). Other scholars stress the geopolitical clarity and relative predictability of a bipolar system. Fewer actors are involved, and although their mutual relations may be antagonistic, they are also in balance (Mearsheimer 1990). Not surprisingly, most Western politicians, pundits and public opinion tend to associate current changes towards a more plural world order with uncertainty and danger. It is associated with the decline of the West and the emergence of new powers. Russia draws the opposite conclusion. Change towards multipolarity is seen as a prerequisite for global peace and security. It is the refusal by the West to accept the emerging reality of multipolarity and their attempts to contain other centres of power, which leads to growing global turbulence and insecurity (Foreign Policy Concept 2016).

Russian discourse on multipolarity has changed over time. During Yeltsin's first presidential term, America was too strong, and Russia's ambition to cooperate with the West still too powerful to seriously consider multipolarity as a realistic foreign policy option. This came from the second half of the 1990s, out of frustration with the continuing unilateralism of the United States and the meagre benefits that its pro-Western, accommodating foreign policy had brought Russia. President Putin never returned to Yeltsin's compliant policies, but especially in the early 2000s, after the terrorist attacks on New York and Washington, he adopted a relatively forthcoming and understanding attitude towards the West. He accepted the necessity of rapprochement and of cooperation with the United States. Russia's benign position lasted less than 3 years. The turning point was the American invasion of Iraq in

\footnotetext{
${ }^{2}$ At the time of writing reports about Russia's interference in the presidential elections in the United States are still too indeterminate to draw conclusions on the extent of involvement of the Russian leadership or on the strategic nature of the intervention.
} 
March 2003. Throughout the 2000s, and especially after the crisis in Ukraine, which Russia blamed on the offensive policies by the United States and the European Union, the approach to multipolarity further developed; from a statement of purpose, it became a statement of reality. In Russia's 2016 Foreign Policy Concept multipolarity is presented as a geopolitical fact, with Russia as one of its 'civilization poles'. 'The world is currently going through fundamental changes, related to the emergence of a multipolar international system', the policy concept states. 'New centres of economic and political power' have arisen. 'Global power and development (...) is shifting towards the Asia-Pacific Region, eroding the global economic and political dominance of the traditional Western powers. The cultural and civilizational diversity of the world and the existence of multiple development models are clearer than ever.'

This reference to civilizational diversity brings in another aspect of Russia's multipolarity, namely its struggle against key ideational aspects of Western-led globalization. Russia's response to globalization is almost as diverse as the reality of globalization itself is. As an energy-exporting power Russia benefited enormously from the economic dynamism and deepening interconnectedness that are often associated with globalization. But globalization is also problematic for Russia.

As the loser of the Cold War, but also as an actor still in possession of significant power resources and thus suspended between great and middling power status, (Russia) has had to rebuild its political and cultural identity, its external security, and its domestic as well as international legitimacy in a situation characterized not only by the turbulence of the immediate historical past but also by the pressure exerted by the economic, political, and cultural forces of Western globalization. (Hedetoft and Blum 2008, 21).

With the brief exception of its first years of independence, Russia tried to resist unwelcome aspects of political, cultural and economic globalization, including the predominance of (Western) liberal democracy, the free market, the qualification of national sovereignty, in short: liberal internationalism. The Foreign Policy Concept of 2000 talked about Russia's firm intention to not only build multipolarity, but to also help to shape the 'ideology' behind it. (National Security Concept of the Russian Federation 2000). The 'national idea' that Putin has been pursuing since his return to the presidency in 2012, in combination with his emphasis on the supreme role of the state in Russia's economic development, are the key components of this ideological endeavour. Russia plays an important part in the proliferation of antiliberal nationalism and state capitalism (Kurlantzick 2016), the two major ideational alternatives to globalization as we know it. 


\subsection{Multilateralism}

Multipolarity and multilateralism are closely related in Russia's foreign policy strategy. Russia's multilateralism serves its ambition of multipolarity. Alternatively, the multilateralism that Russia prefers can only be fully realized in the context of a pluralistic and multipolar world order.

Multilateralism relates to states' policies towards regional and global institutions and organizations. Institutions stand for the rules and regulations which specify how states should interact with each other. Organizations give theses institutions an administrative structure and a degree of operational autonomy. Multilateralism enables countries to work together in a sustained and institutionalized manner, and it differs from integration, which involves the transfer and pooling of countries' sovereignty (Rowe and Torjesen 2009, 1). Few international organizations have sufficient means to enforce their member states to abide by the rules. Generally, the level of states' compliance depends on the extent to which states wish and are able to comply or not.

International Relations theorists differ on the relevance of international organizations in global politics (Hurd 2011). Not surprisingly, given their strongly statecentric view on foreign relations and global politics, realists tend to question the agency of international institutions and organizations. Generally, international organizations reflect the distribution of power at the global or regional level, John Mearsheimer $(1994 / 95,7)$ argues. They are based on the self-interest of powerful states and they have little autonomous impact on the behaviour of states. The role and relevance of international organizations is therefore determined by why and how states use them. And states 'use' them for a variety of self-serving purposes, as instruments to enhance their share of global or regional power, as forums for policy coordination, bargaining or the diffusion of norms and ideas, or as a means to raise their global or regional prestige. To put it simply, international institutions and organizations are what states make of them. Other scholars, especially liberal institutionalists, attach a wider importance to multilateralism.

Liberal institutionalists see the possibility of truly collaborative policies among states, which may produce 'common goods' that go beyond the interests and the capabilities of individual states (Hurd 2011; Rowe and Torjesen 2009, 2). They argue that realists underestimate the utility of international organizations, also to more powerful states. But even most institutionalist would agree that state interests reign supreme. In the end, states define the real-world significance of international institutions and organizations: 'International organizations (...) exist only because states that have created them, and their powers apply only to the extent that states consent to them' (Hurd 2011, 10).

Given the direction of Russian foreign policy in general, it is to be expected that Russia's approach towards international institutions and organizations comes close to the realist interpretation. In the perception of the Russian leadership, multilateralism should reflect Russia's sovereignty, its regional or global status and its special global role and responsibility. Russia's approach towards multilateralism is 
generally perceived as instrumental rather than principled. It largely depends on the power and influence that Russia is able to wield within the variety of multilateral arrangements it participates in. Bobo Lo $(2015,73)$ talks about Russia's 'qualified' multilateralism. Russia 'has observed the letter of multilateralism, while often ignoring its spirit.' Russia's instrumentalist attitude is not unique, but what makes Russia stand out, according to Lo, is the degree to which it exploits its position in multilateral organizations to project its influence, its perceived great power status. Robert Legvold also emphasizes the instrumental nature of Russia's multilateralism. For Russia's leaders multilateralism is not so much a foreign policy norm or principle, but a tool, a means of 'levelling the playing field' (Legvold 2009, 30). Other scholars accentuate the temporal shifts in Russia's multilateralism, from an essentially defensive posture during the 1990s to a more offensive one from the mid-2000s (Bond 2015, 189). Initially Russia aimed to use international organizations to restrain the West, especially in the Kosovo crisis in 1999-2000, and the interventions in Iraq in 2003. This strategy proved largely unsuccessful. Russia lacked the institutional power to effectively influence US decision-making through international institutions and organizations. Later, a more assertive and confident Russia used the same multilateral institutions to legitimize its own international ideas and unilateral behaviour, especially its war against Georgia in 2008 and the annexation of the Crimea in 2014.

More in detail, what are the key features of Russia's multilateralism, or 'multilateral diplomacy' as it is mostly referred to in Russian foreign policy discourse?

First, Russia is a big but also 'lonely' power (Shevtsova 2010). Russia is not a member of any true alliance, except in its own neighbourhood. It has few real enemies or friends. There may not be many compelling reasons for Russia to ally up with or against other countries, but the country even seems reluctant to do so. In the immediate wake of the annexation of the Crimea, at a meeting of the National Security Council, president Putin explained it as follows: 'Russia is fortunately not a member of any alliance. This is also a guarantee of our sovereignty. Any nation that is part of an alliance, gives up part of its sovereignty.' (Putin, July 2014b).

Russia may be a lonely, but it is not an isolationist power. It is present in a wide range of international institutions and organizations, albeit it not, with a few exceptions, very prominently. Russia seeks cooperation, if possible on its own terms, but not integration. Integration would be in conflict with the higher goals of sovereignty and independence. In terms of real and effective engagement, Russia emphasizes a variant of multilateralism, 'great power multilateralism', which facilitates international coordination by leading powers, without questioning the primacy of national sovereignty.

Russia is especially eager to join influential, prestigious 'great power' clubs. The UN Security Council and the G8 (from which it was excluded after the annexation of the Crimea) are the prime examples. Permanent membership of the Security Council provides Russia with the influence and prestige that no other international organization can. It puts Russia on par with the United States and China. Russia understands international 'high' politics predominantly in 'plutocratic' or 'oligarchic' terms. (Lo 2015, 41) Global politics is all about relations among great powers. 
For Russia, this is more than a statement of fact; it comes close to a normative assertion. Great powers have a special responsibility to ensure global stability. 'Russia attaches great importance to ensuring the sustainable manageability of global development', the Foreign Policy Concept of 2016 emphasizes, 'which requires collective leadership by the major states that should be representative in geographic and civilisational terms and fully respect the central and coordinating role of the UN' (Foreign Policy Concept of the Russian Federation 2016). Russia's ideas come close to the nineteenth century notion of the 'Concert of Europe'. Deeply shocked by the turbulences of the Napoleonic Wars (1803-15) the major leaders of Europe agreed on a mutual arrangement that would help to guarantee the stability on the continent. The Concert 'had a deeply conservative sense of mission', the historian Mark Mazower $(2013,5)$ opines. 'Based on respect for kings and hierarchy, it prioritized order over equality, stability over justice.' One should not stretch the comparison too far, but the parallel with Russia's approach to the role of great powers today is hard to avoid. 'Management by Great Powers' (Makarychev and Morozov 2011) may be fundamentally different from multilateralism as it is often understood, but it closely resembles Russia's preferred form of multilateralism. Given the complexity, the interdependence and the volatility of today's world, Russia's Great Power multipolarity does not seem very realistic though. Greater powers do not easily control or contain smaller states anymore. The restrictive and disciplinary decades of the Cold War are behind us.

Secondly, depending on its relative power capacity, Russia has a preference for bilateral over multilateral relations. The default position is multilateralism when possible, bilateralism or unilateralism when necessary. Russia's policies towards the European Union offer a good example. Moscow judged the EU's early strategy of integration (cooperation) through transformation as overly patronizing. What Brussels presented as partnership, Moscow perceived as an asymmetric, hierarchical relationship, which denigrated its status and questioned its sovereignty (Prozorov 2006, ix). From the end of the 1990s, the EU changed its strategy — not so much because of Russia's concerns, but because of a lack of results. The EU cut back on its transformative objectives. It finally aimed to deal with the Russia that was, not with the Russia that it wished to be. EU-Russian relations are deep and diverse, but they have always been problematic, especially at the highest political level. The European Union remains a strange animal to Russia. '(W)ithin the sovereign logic the very entity of the EU is conceived as problematic', as the Russian scholar Sergei Prozorov $(2006,81)$ phrases it, 'unsubsumable under any conventional definition, which makes dealing with "regular" foreign policy actors a preferable option.' If possible, Russia follows a divide-and-rule policy towards the EU. It is in its selfperceived interest to prevent a common European Russia strategy, whether it concerns energy security, sanctions or Europe's neighbourhood policy. Russia prefers to work with the EU member states on an individual basis, bilaterally.

Thirdly, Russia has a strong aversion against multilateralism in the sphere of political values and other normative issues, especially when they reach into the domestic affairs of countries. This approach is clearly reflected in Moscow's 
changed attitude towards the Organization of Security and Cooperation in Europe (OSCE) (Alberts 2016).

During the first phase of the Yeltsin presidency the OSCE was considered as the preferred institutional core of a post-Cold War European security architecture, as an inclusive alternative to NATO. The OSCE developed however in a direction that Russia did not want, but was unable to stop. As Russia saw it, the OSCE, especially through its various semi-autonomous institutions like the Office of Democratic Institutions and Human Rights (ODIHR), increasingly intervened into the internal affairs of its member states, Russia and the other countries in the former Soviet space in particular. The OSCE reported critically on the war against Chechnya and on elections in various post-communist countries. In the perception of Russia, Western countries had turned the OSCE into an instrument aimed against Russia and its interests in the region. Russia initially attempted to change the geographic and thematic direction of OSCE activities, but when that proved futile, it engaged in a more successful strategy of obstruction, of 'obstructive multilateralism' as it were. It succeeded to effectively marginalize the OSCE as an all-European institution.

After the annexation of the Crimea and the military conflict in the eastern part of Ukraine, Russia partly reconsidered its position towards the OSCE. It hesitantly accepted the presence of OSCE monitors in the region and participated in negotiations within the OSCE framework about the future status of eastern Ukraine. Lack of organizational alternatives, apart from summit meetings with the leaderships of Ukraine, France, Germany and the United States, and especially Russia's prevailing influence on the conflict (its enhanced 'institutional power' and agenda-setting capacity in the OSCE), explains Russia's more cooperative attitude.

Fourthly, there is a range of partial explanations why Russia's multilateralism is instrumental and conditional, rather than normative and principled. The bottom-line is power, or rather the lack thereof. To understand Russia's multilateralism and its approach towards international organizations 'institutional power' as defined by Michael Barnett and Raymond Duval $(2005,51)$ is a crucial variable. Institutional power is the extent to which states have the capacity to influence other states in indirect ways, especially through the rules and procedures of formal and informal institutions. In comparison with the United States, architect and linchpin of the liberal global order, with other leading Western powers, and increasingly also with China, Russia's capability to influence international organizations, and through these organizations the behaviour of other states is rather limited. Russia can adapt to the global order, which it did after the collapse of the Soviet Union, or it can try to balance within institutions (UN Security Council) or between institutions (OSCE versus NATO; the BRICS' New Development Bank versus the World Bank and the International Monetary Fund). But to challenge the liberal order, Russia needs more powerful partners, China in particular.

Also in the UN at crucial moments, Russia lacked the capacity to steer Security Council deliberations into the preferred direction. In the 1990s Russia repeatedly attempted to either prevent or reduce sanctions against Sadam Hussein's Iraq. It was of no avail. Russia saved Iran from sanctions a number of times, but eventually it concurred with the tougher approach by the United States and its European allies. 
Russia's relations with Iran are important for economic and geopolitical reasons. After the US invasion had effectively destroyed Iraq as a regional power, Iran began to play an increasingly prominent role in the wider Middle East, its influence reaching as far as Central Asia and the Caucasus. Russia assisted Iran in the development of its nuclear industry, including the construction of the Busher power plant, and benefited from its revenues. Still, Russian-Iranian relations have always remained challenging. Russia may have had its own reasons to worry about Iran's nuclear ambitions, but in this dossier relations with its Western partners clearly trumped its links with Iran. Russia's equal participation made the P5 +1 (Germany), plus the European Union, an acceptable format for nuclear negotiations with Iran. In 2015 all parties agreed on the Iran Nuclear Deal Framework, a reduction and redirection of Tehran's nuclear programme in exchange for the lifting of sanctions. The deal was one of the few complex and controversial agreements that Russia, the United States and the Europe Union reached since the annexation of the Crimea. In 2018 the United States abandoned the deal. It should be added that over the years neither Iran nor Iraq proved particularly grateful for Russia's efforts. At crucial moments they persisted in their uncompromising and confrontational behaviour, also against the expressed interests of the Russian Federation.

In March 2011 Russia abstained in the UNSC on the vote which established a no-fly zone over Libya, but it was ineffective to prevent Western powers from using the resolution as a go-ahead for a full military operation against the Qaddafi regime. It is not in Russia's or in any other permanent member state's interest to use its vetopower too frequently. Vetoes in the Security Council are 'rare' (Ferdinand 2013, 4). States neither want to isolate themselves, nor do they want to risk the devaluation of the Security Council as the world's highest, most powerful centre of decisionmaking. So when it comes to a vote in the Security Council, which in itself does not occur very often, Russia and China, who frequently coordinate their positions, rather abstain from voting than veto unwelcome decisions (Ferdinand 2013). All the more remarkable were their three vetoes in 2011 and 2012 against resolutions that called upon the Bashar al-Assad regime in Syria to refrain from military violence against its own people and, later, to step down. The vetoes were indicative of the deep aversion by the two powers against intervention into the domestic affairs of other countries, whether sanctioned by the Security Council or not.

And finally, and most importantly, when discussing Russia's engagement with multilateralism, a distinction needs to be made between its general strategy and its approach towards the countries in its immediate geopolitical environment, the countries of the Former Soviet Union.

\subsection{Russia in its Geopolitical Neighbourhood}

The post-Soviet countries have never been just 'abroad' for Russia. Referred to during the 1990s as the 'Near Abroad', Russia has always claimed special responsibility for its geopolitical environment (Donaldson et al. 2014; Lo 2015; Sherr 2013). Russia believes to have 'a legitimate right of intervention', as Lo (2015, xxi) puts it. 
Different foreign policy rules apply. Russia's special relationship with the former Soviet republics not only stems from conventional security concerns, but also from a sense of entitlement that is based on a perceived common history and culture, and on Russia's predominant position in the region. In the wake of the war with Georgia, president Medvedev presented the five principles of Russian foreign policy, including the 'privileged interests' that Russia claims in regions, where 'there are countries with which we have traditionally had friendly cordial relations, historically special relations. We will work very attentively in these regions and develop these friendly relations with these states, with our close neighbours.' When asked if these regions bordered on Russia, Medvedev answered: 'Certainly the regions bordering (on Russia), but not only them' (The Economist, 1 September 2008).

Developments in the countries of the FSU, in Russia increasingly referred to as Eurasia, can have an immediate impact on the security of the Russian Federation. The former Soviet space is a geopolitically contested and volatile part of the world. The countries border areas of deep instability and conflict: the Southern Caucasus, the Middle East, Afghanistan and Pakistan. The FSU forms a shared neighbourhood with other major power, with the European Union in the West, and with China in Central Asia. Arguably Russia has extensive and legitimate interests in the region, not only traditional security interests, like political stability and controllable borders, but also economic interests, especially in the sphere of energy and energy transport.

Russia's policies in Eurasia go beyond traditional security interests though. They should be seen as parts of a larger geopolitical project. Russia aspires to create a strong, dynamic regional order under its own leadership, not only to serve its own economic interests, but also to build a block towards the global multipolar order it envisions.

Scholars present different interpretations of Russia's multilateral strategy towards its neighbouring countries. Legvold (2009, 32-33) talks about 'multilateralism in concentric circles'. He distinguishes between Russia's different but interrelated strategies towards the Former Soviet Union, other neighbouring countries, and the wider world. Julian Cooper opines that Russia's policy in the region cannot be characterized as one of multilateralism, not even in its 'great power form'. He prefers 'hegemonic bilateralism'. (Cooper 2009, 179) Another distinction is between reactive and competitive Russian multilateralism in the former Soviet space. (Allison 2004) Reactive multilateralism is primarily aimed against growing inroads by Western states and institutions in the region (especially affiliation with NATO and the European Union); while competitive multilateralism is focussed on building multilateral institutions which serve Russia's (and allegedly the other countries') political and economic interests. Both variants are present in Russia's policies towards the Former Soviet Union, agrees also Stina Torjesen. Although, as she adds, 'the timing of Russia's multilateral activities strongly points to the former' (Rowe and Torjesen 2009, 17; Torjesen 2009). Russian multilateralism in Eurasia is particularly aimed at keeping others out, she concludes. And Putin apparently agrees. Speaking to a conference of Russian ambassadors in July 2004, he warned against the risk of a 'vacuum' in international relation: '(were) Russia to abstain from an 
active policy in the Commonwealth of Independent States or even embark on a unwarranted pause, this would inevitably lead to nothing else but other, more active, states resolutely filling this political space' (Quoted in Adomeit 2007, 22).

Bobo Lo's $(2015,128)$ stresses that Russias policies towards the countries of the FSU have generally been more pragmatic than messianic, more defensive than offensive, and rather declining in terms of power and influence than increasing (See also Donaldson et al. 2014, 383; Rowe and Torjesen 2009, 14). Given the persistency with which the Russian leadership has expressed the priority of deepening bilateral and multilateral ties in the region, the actual level of integration is indeed disappointing. Too little resolve on the part of Russia cannot be the explanation, although also in its relations with other Eurasian countries Russia has shown more enthusiasm for bilateral over multilateral forms of cooperation. It is hesitancy by the other countries to join or further develop Russian-led organizations that mostly accounts for the lack of progress. The other republics are careful to engage too deeply in formalized cooperation with Russia. Experience with Russia's (past) imperial behaviour and its overbearing weight among the former Soviet republics are the major explanatory factors. Membership of multilateral organizations in the Former Soviet Union fluctuated with the degree to which the member states' leaderships felt the aspiration and had the capacity to widen or narrow their distance from Russia.

In December 1991 ten former Soviet republics joined Russia in the Commonwealth of Independent States (CIS). The CIS was the first multilateral institution in the former Soviet space. The CIS served its purpose as a means of policy coordination between Russia and the other members during the hectic and volatile times around the collapse of the Soviet Union, but it never developed into a real multilateral organization. Throughout the years, the share in world trade by the countries of the CIS remained marginal (with the exception of Russia's energy and arms exports) and mutual trade even decreased (Cooper 2009, 167). Security issues remained outside of the CIS framework. They are mostly discussed within the Collective Security Treaty Organization. The CSTO was established in May 1992 and has partly overlapping membership with the Shanghai Cooperation Agreement (SCO), which also includes major non-regional powers like China.

The first steps towards a free trade regime or customs union in the Former Soviet Union (FSU) were taken in October 2000. Russia, Belarus, Kazakhstan, Kyrgyzstan and Tajikistan established the Eurasian Economic Community. In 2006 they were joined by Uzbekistan. Moldova and Ukraine required an observer status in May 2002, followed in 2003 by Armenia. In the ambition of the Russian leadership the Eurasian Economic Community would progress towards a single economic space, a common market, and eventually a full supranational organization. And indeed, through various organizational stages and in different membership constellations, the Eurasian Economic Community eventually developed into a Eurasian Economic Union or just Eurasian Union, starting from January 1, 2015. In May 2014, Russia, Kazakhstan and Belarus (Armenia and Kyrgyzstan would join the Union later that year) signed the Treaty on the Eurasian Economic Union in Astana. At the occasion, Putin described the founding of the Union as an 'epoch-making' event (Putin, May 2014a). 
It is too early to tell if the Eurasian Union represents a qualitatively new form of cooperation in the post Soviet space. The establishment of the Union was accompanied by reassurances, by Putin, and emphasises, especially by the Kazakh leader Nursultan Nazarbayev, that the treaty would neither limit nor violate any of the signatories' sovereignty. An early assessment of the institutional framework of the Union confirms that it is only weakly supranational and with minor infringements on the national authority of its members. The mode of decision-making remains firmly intergovernmental, and centred at the highest level of state authority (Dragneva 2016).

The Shanghai Cooperation Organization (SCO) was established in 2001, when Uzbekistan joined the member states of the original 'Shanghai Five' (1996), Russia, China, Kazakhstan, Kyrgyzstan, and Tajikistan. The SCO is different from any other multilateral organization in the former Soviet space, because it includes China. Russia and China seem to have partly diverging ambitions for the organization though. Whereas China sees the SCO primarily as a means to expand its economic influence in the Eurasian region; Russia positions it within the larger security context of its relationship with its powerful neighbour (Donaldson et al. 2014, 290). For the Russian leadership, security cooperation with China is a highly valuable component of its balance-of-power approach, its global multipolarity, which is primarily envisioned against the United States, its allies and their liberal world order.

Despite these diverging ambitions and notwithstanding Russia's historically unique junior position vis-à-vis China, the Russian leadership has repeatedly expressed its great appreciation of the SCO. Putin called the SCO his 'preferred model of multilateralism.' (Cited by Torjesen 2009, 182).

The key difference between Russia's engagement with multilateralism in general and its strategy towards the former Soviet republics is Russia's institutional power. The FSU is the only part of the world where Russia wields significant institutional power. Still, the discourse on special responsibilities and vital interests are not necessarily indicative of the level of influence which Russia is able to exercise over the countries in its neighbourhood. Russia's influence in the region remains contested, by outside powers like China and the European Union, but mostly by the partnercountries themselves. Mutual relations between Russia and the other republics of the former Soviet Union are diverse (as does their importance for Russia) and they are volatile. Some countries have generally been close to Russia, also for lack of alternatives (Armenia, Belarus, Tajikistan, and with reservations Kazakhstan); others keep their distance (Uzbekistan), and others again vacillated, pulling Russia closer and then pushing it away again, largely conditioned by the preferences of their leaderships (Georgia and Ukraine).

Paradoxically, Russia's predominance among the former Soviet republics has mixed consequences. It enables Russia to claim a leading role in the area, but it also makes the other countries cautious not to give up too much of their sovereignty. Russia's population is almost five times bigger than the numbers of the three other members of the Eurasian Union combined. Russia's area size is almost eight times larger. Russia's GDP is seven times bigger. At its inception, the Eurasian Union is a 
much more heterogeneous club of nations than the European Economic Community was in 1957. At that time, as the largest member of the Community, Germany's population share and GDP were $32 \%$ and $40 \%$ of the EEC's total, respectively. ${ }^{3}$ Russia is simply too big and too powerful to be a comfortable partner for the countries in its neighbourhood.

\subsection{Conclusion}

The worldview of the current Russian leadership is simple and straightforward: Russia is a great power or Russia is not. With a reference to Russia's size and location, its unique history and culture, and massive economic and military resources Putin claims a prominent role for Russia in the global order today. Russia deserves a great power status. Actually, in order to survive, Russia needs to be a great power.

The foreign policy strategy which Russia's post-communist leadership developed from this worldview, has generally been pragmatic, relatively prudent and not particularly confrontational. Multipolarity is Russia's major foreign policy ambition. Russia believes in global politics that are based on the cooperation and if necessary on the competition between 'poles', led by equal, sovereign great powers. Russia aspires to be one of those poles.

Throughout the post-Cold War decades, Russia's idea on how global politics (should) work have largely remained constant; its foreign policies however evolved. Partly due to developments which were beyond Russia's influence and partially as a result of political and economic changes in Russia itself, the country's foreign policies became more self-confident, more assertive and more offensive, initially especially in its own environment but later also beyond its sphere of influence. The longer-term trends and ambitions of Russian foreign policy have not changed though, and neither have its remarkable paradoxes. Russia wants to revise the liberal global order and she wants to be a prominent part of it. Russia is a revisionist power, but with a strongly conservative streak. Russia demands the right to be included, but it also wants to stand apart. Russia is strongly in favour of multilateralism, but preferably a multilateralism for the few, for great powers only—Russia included.

\footnotetext{
${ }^{3}$ The inspiration to compare the Eurasian Union with the European Economic Community comes from Blockmans, Kostanyan and Vorobiov 2012, who also give the figures on Germany. The figures for the countries of the Eurasian Union come from different web sources, including the World Bank.
} 


\section{Further Reading}

Russian foreign policy is the topic of a dazzling number of academic and policy-related studies. The interested reader may begin with the series of brilliant essays in Russian Foreign Policy in the Twenty-First Century and the Shadow of the Past, edited by Robert Legvold (2007). The book offers fascinating insights into the longer-term, historical continuities of Russian foreign policy. Robert Donaldson, Joseph Nogee and Vidya Nadkarni (2014, fifth edition) present a well-structured, balanced and chronological overview of Russia's international policies in The Foreign Policy of Russia. Changing Systems, Enduring Interests. The best study of Putin's foreign policies is Russia and the New World Disorder by Bobo Lo (2015). The book is topical, thorough and admirably objective.

\section{References}

Adomeit, H. (2007). Inside or outside? Russia's policies towards NATO. Paper delivered to the annual conference of the Centre for Russian Studies at the Norwegian Institute of International Affairs (NUPI) on "The Multilateral Dimension in Russian Foreign Policy", Oslo, October 12-13, Revised December 20, 2006.

Alberts, Hannah Claire (2016). Russia's OSCE policy and the Ukraine crisis: Renewed interest, enduring approach. Thesis master of global policy studies and master of arts. Austin: The University of Texas.

Allison, R. (2004). Regionalism, regional structures and security Management in Central Asia. International Affairs, 80(3), 463-483.

Allison, R. (2013). Russia and Syria: Explaining alignment with a regime in crisis. International Affairs, 89(4), 795-823.

Barnett, M., \& Duvall, R. (2005). Power in international Politics. International Organization, 59(1), 39-75.

Blockmans, S., Kostanyan, H., \& Vorobiov, I. (2012). Towards a Eurasian economic union: The challenge of integration and unity. Brussels: CEPS.

Bond, I. (2015). Russia in international organizations: The shift from defence to offence. In D. Cadier \& M. Light (Eds.), Russia's foreign policy. Ideas, domestic politics and external relations (pp. 189-203). Houndmills/Basingstoke: Palgrave Macmillan.

Cooper, J. (2009). Russia's trade relations within the commonwealth of independent states. In E. W. Rowe \& S. Torjesen (Eds.), The multilateral dimension in Russian foreign policy. New York: Routledge.

Donaldson, R. H., Nogee, J. L., \& Nadkarni, V. (2014). The foreign policy of Russia. Changing systems, enduring interests. In Armonk. New York/London: M.E. Sharpe.

Dragneva, R. (2016). The Eurasian economic union: Balancing sovereignty and integration. Institute of European Law. Working Paper 10. University of Birmingham.

The Economist. Medvedev on Russia's interest. http://www.economist.com/blogs/ certainideasofeurope/2008/09/medvedev_on_russias_interests

Ferdinand, P. (2013). The positions of Russia and China at the UN Security Council in the light of recent crises. European Parliament/Directorate-General for External Policies. Brussels.

The Foreign Policy Concept of the Russian Federation. (2008). http://en.kremlin.ru/ supplement $/ 4116$

The Foreign Policy Concept of the Russian Federation. (2016). http://www.mid.ru/en/ foreign_policy/official_documents//asset_publisher/CptICkB6BZ29/content/id/2542248

Gerrits, A., \& Bader, M. (2015). Russian patronage over Abkhazia and South Ossetia: Implications for conflict resolution. East European Politics, 32(3), 297-313. 
Hedetoft, U., \& Blum, D. W. (2008). Introduction: Russia and globalization-A historical and conceptual framework. In D. W. Blum (Ed.), Russia and globalization. Identity, security, and society in an era of change. Washington, DC/Baltimore: Woodrow Wilson Center Press/The Johns Hopkins University Press.

Huntington, S. P. (1996). The clash of civilizations and the remaking of world order. New York: Simon \& Schuster.

Hurd, I. (2011). International organizations. Politics, law, practice. Cambridge: Cambridge University Press.

Kropatcheva, E. (2016). Russia and the collective security treaty organisation: Multilateral policy or unilateral ambitions? Europe-Asia Studies, 68(9), 1526-1552.

Kuchins, A. C., \& Zevelev, I. A. (2012). Russian foreign policy: Continuity in change. The Washington Quarterly, 35(1), 147-161.

Kurlantzick, J. (2016). State capitalism. How the return of Statism is transforming the world. New York: Oxford University Press.

Larson, D. W., \& Shevchenko, A. (2010). Status seekers. Chinese and Russian responses to U.S. primacy. International Security, 34(4), 63-95.

Larson, D. W., \& Shevchenko, A. (2014). Russia says no: Power, status and emotions in foreign policy. Communist and Post-Communist Studies, 47, 269-279.

Laruelle, M. (2010). In the name of the nation. Nationalism and Politics in contemporary Russia. New York: Palgrave Macmillan.

Legvold, R. (2009). The role of multilateralism in Russian foreign policy approaches. In E. W. Rowe \& S. Torjesen (Eds.), The multilateral dimension in Russian foreign policy. New York: Routledge.

Levitsky, S., \& Way, L. A. (2010). Competitive authoritarianism. Hybrid regimes after the cold war. New York: Cambridge University Press.

Lieven, A. (1999). The weakness of Russian nationalism. Survival, 41(2), 53-70.

Lo, B. (2015). Russia and the new world disorder. London/Washington, DC: Chatham House/ Brookings Institution Press.

MacFarlane, S. N. (2006). The 'R' in BRICs: Is Russia an emerging power? International Affairs, 82(1), 41-57.

Makarychev, A., \& Morozov, V. (2011). Multilateralism, multipolarity, and beyond: A menu of Russia's policy strategies'. Global Governance, 17, 353-373.

Mazower, M. (2013). Governing the world. The history of an idea. London: Penguin Books.

Mearsheimer, J. (1990). Back to the future: Instability in Europe after the Cold War. International Security, 15(1), 5-56.

Mearsheimer, John (1994/95). The false promise of international institutions. International Security 19(3), 5-49.

National Security Concept of the Russian Federation. (2000). http://www.mid.ru/en/foreign_policy/ official_documents//asset_publisher/CptICkB6BZ29/content/id/589768

O’Neill, J. (2001). Building better economic BRICs. Global Economics Paper No: 66. New York, etc., Goldman Sachs.

Phillips, C. (2016). The Battle for Syria. International Rivalry in the New Middle East. New Haven/London: Yale University Press.

Prozorov, S. (2006). Understanding conflict between Russia and the EU. The limits of integration. Houndmills/Basingstoke: Palgrave Macmillan.

Putin, V. (2012, February). Russia and the changing world. Moskovskiye Novosti February 27, 2012. Johnson's Russia List, 2012, 34.

Putin, V. (2013, September). Meeting of the Valdai International Discussion Club, 19 September. Retrieved from http://eng.kremlin.ru/news/6007

Putin, V. (2014a, May). Putin: Peredacha polnomochnyi v EAEU ne osnachayet utratu suverenita. https://ria.ru/economy/20140529/1009842639.html

Putin, V. (2014b, July). Security council meeting. Vladimir Putin chaired a security council meeting in the Kremlin. Retrieved from http://en.kremlin.ru/events/president/news/46305 
Riasanovsky, N. V. (2005). Russian identities. A historical survey. Oxford: Oxford University Press.

Rowe, E. W., \& Torjesen, S. (2009). Key features of Russian multilateralism. In E. W. Rowe \& S. Torjesen (Eds.), The multilateral dimension in Russian foreign policy. New York: Routledge.

Sakwa, R. (2016). How the Eurasian elites envisage the role of the EEU in global perspective. European Politics and Society, 17(1), 4-22.

Sergunin, A. A. (2004). Discussions of international relations in post-communist Russia. Communist and Post-Communist Studies, 37, 19-35.

Sherr, J. (2013). Hard diplomacy and soft coercion. Russia's influence abroad. London: Chatham House.

Shevtsova, L. (2010). Lonely power. Why Russia has failed to become the west and the west is Weary of Russia. Washington, DC: Carnegie Endowment for International Peace.

Snyder, J. (2000). From voting to violence. Democratization and nationalist conflict. New York: Norton.

Torjesen, S. (2009). Russia as a military great power: The uses of the CSTO and the CSO in Central Asia. In E. W. Rowe \& S. Torjesen (Eds.), The multilateral dimension in Russian foreign policy. New York: Routledge.

Tsygankov, A. P. (2012). Russia and the west from Alexander to Putin. Honor in international relations. Cambridge University Press.

Tsygankov, A. P., \& Tsygankov, P. A. (2003). New directions in Russian international studies: Pluralization, westernization, and isolationism. Communist and Post-Communist Studies, 37, $1-17$.

World Bank. (2015). Gross domestic product 2015. http://databank.worldbank.org/data/download/ GDP.xls 